\title{
Penggunaan Paradigma Integrasi- Interkoneksi dalam Proses Pembelajaran di Program Pascasarjana UIN Sunan Kalijaga Yogyakarta
}

DOI 10.18196/AIIJIS.2017.0069.110-140

\begin{abstract}
AHMAD IZUDIN
Universitas Islam Negeri Sunan Kalijaga, Yogyakarta

ahmad.izudin@uin-suka.ac.id
\end{abstract}

\section{ABSTRACT}

This article analyzes the utilization of integrative and inter-connective concepts in the learning process of Islamic studies at the graduate program in State Islamic University of Sunan Kalijaga. This study explores the experiences of lecturers and students at the interdisciplinary Islamic studies at the graduate program. Based on the interview and observation, the author highlights two types of learning processes. First, lecturer at UIN Sunan Kalijaga have inserted notions integrative and inter-connective concepts as well as Islamic values and interdisciplinary approach in their syllabus and learning plan. Second, students have given various responses to the way lecturers teach in the class. According to students, lecturers graduated from western educational institutions, either Europe or America, stimulated students to think critically use interdisciplinary approach in resolving the problems. There are also some lecturers who use a normative approach in conceiving the debates and critical thinking in Islamic studies.

Keywords: critical thinking, integrative and inter-connective paradigm, learning process

\section{ABSTRAK}

Artikel ini menganalisis penggunaan konsep integrasi dan interkoneksi dalam proses pembelajaran studi Islam di program Pascasarjana UIN Sunan Kalijaga. Artikel ini mengekplorasi pengalaman dosen dan mahasiswa di program studi studi Islam interdisipliner di pascasarjana UIN Sunan Kalijaga. Berdasarkan hasil wawancara dan pengamatan, penulis memberikan perhatian terhadap dua hal utama. Pertama, para dosen di UIN Sunan Kalijaga telah menerapkan konsep integrasi dan interkoneksi dan memasukan nilai-nilai Islam dan pendekatan multidisiplin di dalam silabus dan rencana pembelajaran. Kedua, para mahasiswa 
memberikan berbagai respons terhadap pengalaman mereka di kelas. Menurut mahasiswa, para dosen lulusan dari Barat, baik Eropa maupun Amerika, telah mendorong mahasiswa untuk berfikir secara kritis dan menggunakan berbagai pendekatan dalam menyelesaikan masalah. Terdapat juga para dosen yang menggunakan pendekatan normatif dalam memahami perdebatan dan pemikiran kritis dalam studi Islam.

Kata Kunci: pemikrian kritis, paradigm integrase dan interkoneksi, proses pembelajaran.

\section{PENDAHULUAN}

Perkembangan ilmu pengetahuan di era modern telah membawa arah baru pada ranah paradigma berpikir, landasan teoritis hingga aplikasi ilmu. Konsekuensi tersebut menuntut civitas akademika meresponnya secara aktif dan progresif agar proses pendidikan dan pembelajaran di tingkat perguruan tinggi/universitas Islam, khususnya bagi program Pascsarjana, tidak ketinggalan.

Merespon persoalan-persoalan ilmu pengetahuan tak ubahnya seperti meletakan pondasi bangunan rumah. Jika batu pertama salah meletakan maka kondisi bangunan yang dilanjutkan akan mengalami pergeseran, bahkan bisa saja roboh akibat tekanan bangunan di atasnya. Analogi ini membawa civitas akademika pendidikan tinggi terus berupaya merespon pembaharuan dalam rekontruksi metodologi ilmu pengetahuan. Terlebih, kini dihadapkan pada masalah social science yang menuntut untuk merubah paradigma. Istilah perubahan cara pandang ini dikenal dengan dikhotomi ilmu pengetahuan. ${ }^{1}$ Di Perguruan Tinggi Islam dikenal dengan dikhotomi antara ilmu agama dengan ilmu-ilmu umum. ${ }^{2}$ Untuk menjawab persoalan ini, maka UIN Sunan Kalijaga menawarkan tawaran konsep integrasi-interkoneksi. Karena itu, adanya spesialisasi ilmu adalah sebuah keniscayaan, karena keterbatasan manusia untuk mengetahui semuanya, walaupun obyeknya sama yakni alam. ${ }^{3}$

Tawaran Integrasi-Interkoneksi-saling sapanya ilmu agama dengan ilmu-ilmu umum — di awali ketika transformasi IAIN Sunan Kalijaga menjadi Universitas Islam pada tahun 2004. ${ }^{4}$ Alternatif paradigma ini berbanding lurus dengan lahirnya fakultas-fakultas baru di lingkungan UIN Sunan Kalijaga, seperti Fakultas Sains dan Teknologi, terakhir Fakultas Ekonomi dan Bisnis Islam. Termasuk di dalamnya perkembangan kajian ilmu pengetahuan Islamic Studies. Di tingkatan Pascasarjana pengembangan Islamic Studies telah melahirkan jurusan Interdisciplinary Islamic Studies 
yang awalnya hanya memiliki satu konsentrasi, yakni Pekerjaan Sosial. Namun, proposal pengembangan tersebut dilanjutnya pada tahun 2009 dengan lahirnya konsentrasi Ilmu Perpustakaan dan Informasi (IPI). Hingga saat ini jurusan IIS memiliki dua konsentrasi yaitu Pekerja Sosial dan IImu Perpustakaan dan Informasi (IPI).

Seiring berjalannya waktu, kedua konsentrasi tersebut mendapatkan respon dari mahasiswa, dosen maupun pemegang kebijakan Universitas yang cukup beragam. Karena rumpun ilmu dari konsentrasi ini cukup membuat bingung sebagian pihak, yakni Pekerja Sosial dengan rumpun IImu Sosiologi dan IPI masuk dalam rumpun IImu Humaniora. Konteks ini kemudian direspon dengan baik, hingga kini UIN Sunan Kalijaga memiliki Sekolah Pasca di bawah naungan Interdisiplinary Islamic Studies dan Pascasarjana di bawah fakultas masing-masing di lingkungan universitas. $^{5}$

Kajian ini berangkat dari pengkajian yang sebelumnya masih terintegrasi di pusat program pascasrjana, tidak seperti saat ini sudah kembali ke fakultas masing-masing di lingkungan universitas (Baca: UIN). Berangkat dari kedua term inilah perlunya melihat respon para stakeholder yang memahami jurusan IIS sebagai wadah yang menjelaskan dari kedua rumpun ilmu yang berbeda di atas. Ini artinya bahwa paradigma integrasiinterkoneksi secara keilmuan harus ada hal baru pada pendekatan metodologi. Pada ranah aplikatif materi-materi yang disajikan dalam Rencana Pembelajaran Semester (RPS) paling tidak memiliki indikator penyampaian materi yang memiliki keterkaitan sama antara Pekerja Sosial dengan Ilmu Perpustakaan dan Informasi.

Maka dari itu, dari permasalahan-permasalahan di atas, artikel ini mencoba untuk membangun landasan dan kerangka berfikir bagi pengembangan prodi IIS pada ranah aplikasi metodologi cross pack pembelajaran. Kajian ini harapannya menjadi acuan dalam pengembangan keilmuan sosial-humaniora yang jelas baik secara filosofis, administratif maupun praktis bagi perkembangan prodi IIS di Pascasarjana UIN Sunan Kalijaga. Maka kajian ini membangun persepsi bersama, antara lain terkait dengan aplikasi paradigma integrasi-interkoneksi yang telah diterapkan dan prosesnya dalam pembelajaran di prodi IIS Program Pascasarjana UIN Sunan Kalijaga. Dan, tanggapan mahasiswa terhadap aplikasi paradigma integrasi-interkoneksi tersebut.

Kajian ini adalah pengembangan hasil penelitian lapangan (field re- 
search) yang menggunakan pendekatan kualitatif. Sumber data dalam kajian ini disebut juga sebagai instrumen penelitian. Oleh karena itu, saya sebagai instrumen penelitian harus divalidasi agar peneliti siap dan mengerti lebih jelas terkait wawasan keilmuan tentang obyek yang sedang dikaji. Untuk itu, sumber data juga kerap dipandang sebagai narasumber (informan) yang dijadikan sumber utama (primer) dalam penelitian. Maka peneliti kualitatif sebagai human instrument, berfungsi menetapkan fokus penelitian, memilih informan sebagai sumber data. Selanjutnya otoritas peneliti pada kajian ini memilih 10 narasumber utama (primer), terdari dari 3 Dosen Konsentrasi IPI, 3 Dosen Konsentrasi Pekerjaan Sosial, 2 Mahasiswa IPI dan 2 Mahasiswa Pekerjaan Sosial. Pemilihan sepuluh informan ini berdasarkan fakta bahwa mereka ikut terlibat langsung dalam proses pembelajaran di Prodi IIS dan mengetahui proses pembelajaran tersebut. Sehingga melalui mereka, persoalan mengenai aplikasi integrasi interkoneksi di IIS dapat diketahui. Teknik pengambilan data dalam kajian ini dilakukan dengan berbagai cara, yakni observasi, indepth interview (wawancara mendalam), studi dokumentasi dan observasi.

Teknik analisis data yang dilakukan adalah proses pemilihan, pemusatan perhatian pada penyederhanaan, pengabstrakan dan transformasi data kasar yang muncul dari catatan-catatan di lapangan. Proses ini merupakan sebuah proses yang berulang selama proses penelitian kualitatif berlangsung. Karena tujuan dilakukannya proses ini adalah untuk lebih menajamkan, menggolongkan, mengarahkan, membuang bagian data yang tidak diperlukan serta mengorganisasi data. Maka hal tersebut dapat memudahkan peneliti untuk melakukan penarikan kesimpulan. Pengecekan keabsahan data merupakan konsep penting dalam penelitian kualitatif. Adapun teknik yang digunakan peneliti untuk memperoleh hasil yang maksimal dalam validasi penelitian maka digunakan pengecekan sebagaimana berikut, yaitu: (a) memperpanjang kehadiran peneliti di lokasi penelitian sehingga dapat mengamati dengan teliti seluruh kegiatan dilokasi penelitian; (b) observasi yang mendalam terhadap aspek-aspek yang terkait dengan aplikasi integrasi-interkoneksi pembelajaran pada prodi IIS; (c) trianggulasi mengecek keabsahan data yang sudah ada pada sumber atau narasumber lain dengan cara dan waktu yang lain. Melalui trianggulasi ini diharapkan tidak ada lagi data ganjil yang diperoleh peneliti di lapangan, karena telah dilakukannya kroscek data melalui sumber data berbeda dan waktu yang berbeda pula. 


\section{ANATOMI PENGKLASIFIKASIAN ILMU}

Pengklasifikasian ilmu telah lama dilakukan oleh para filosof. Mulai dari filosof Yunani kuno hingga filosof modern seperti Socrates, Plato, Aristoteles, Imanuel Kant dan lain sebagainya. ${ }^{6}$ Dalam tradisi Islam kita kenal dengan al-Ghazali dalam kitabnya Ihya 'Ulum al-Din dan Ibn Khaldun dalam karyanya Muqaddimah ${ }^{8}$ mengklasifikasikan ilmu pengetahuan (science) berdasarkan kategori-kategori yang berbeda, namun memiliki pemilahan yang jelas sesuai masing-masing rumpun dan disiplin keilmuannya.

Di era modern, pengklasifikasian ilmu pengetahuan telah megalami perubahan yang cukup kuat. Dengan lahirnya tokoh-tokoh ilmuwan kontemporer yang menawarkan gagasan-gagasan ide pengklasifikasian ilmu baru. Seperti halnya dalam karya Osman Bakar, Classification of Knowledge in Islam, menelaah ulang sebagian karya-karya di atas melalui uraian dan analisis isi kandungan serta metodologisnya. ${ }^{9}$ Karya yang tersebut melahirkan sebuah paradigma berpikir baru di era kekinian. Di mana penjelasan dari hasil intelektual tersebut dapat berkembang dan dapat dipertanggungjawabkan secara rasional dan argumentatif.

Di Indonesia, ilmuwan yang mampu menjelaskan pengklasifikasian ilmu pengetahuan baru ada Mulyadi Kartanegara dalam karyanya Integrasi Ilmu: Sebuah Rekonstruksi Holistik, merujuk kepada sebagian karya-karya di atas yang membahas mengenai pembidangan ilmu pengetahuan berdasarkan rumpunnya dengan penekanan pada pengintegrasian ilmu pengetahuan, yang menegasikan dikotomi ilmu-ilmu agama dan ilmu-ilmu umum. ${ }^{10}$ Menurutnya, apa yang telah dilakukan oleh para ilmuan Muslim pada masa klasik dan pertengahan mengenai klasifikasi ilmu pengetahuan, seperti yang dilakukan al-Ghazali, bukan merupakan pendikotomian ilmu pengetahuan umum dan agama atau sebaliknya. Melainkan ia merupakan suatu bentuk pemilahan terhadap disiplin keilmuan berdasarkan cakupan dan kandungannya.

Di tingkatan Perguruan Tinggi Islam/Universitas, khususnya UIN Sunan Kalijaga, pengklasifikasian keilmuan tersebut telah dilakukan sebagai motor penggerakan pembaharuan pengetahuan tersebut adalah Amin Abdullah yang menawarkan gagasan integrasi-interkoneksi antara ilmu agama dengan ilmu-ilmu umum. ${ }^{11}$ Awalnya, ide itu dalam rangka mempersiapkan konversi dari IAIN menjadi UIN, sudah barang tentu persiapan tersebut tidak hanya secara fisik ataupun administratif tetapi secara software 
pengembangan pengajaran harus dipersiapkan pula. Sehingga kewajiban untuk membangun kurikulum dan sistem pengajaran tersebut kemudian muncul gagasan mengenai tawaran integratif-interkonektif ilmu pengetahuan. $^{12}$

Sejalan dengan adanya rekonstruksi ilmu-ilmu ke-Islaman, beriringan pula dengan lahirnya fakultas-fakultas yang basis pengetahuan umum seperti Fakultas Sains dan Teknologi, Fakultas Ekonomi dan Bisnis Islam, sehingga lahir pula rekonstruksi ide pada kajian Islamic Studies yang melahirkan jurusan Interdisciplinary Islamic Studies pada program Pascasarjana UIN Sunan Kalijaga. Pada awalnya, jurusan tersebut merupakan program kerjasama antara Kementerian Agama dengan McGill University Kanada yang diberi nama proyek Indonesia Social Equity ProjectCanadian International Development Agency (IISEP-CIDA). Pada level Universitas kerjasama tersebut melahirkan konsentrasi Social Work (2003).

Sejak kerjasama tersebut putus-asalnya program IIS kelas internasional_-pada tahun 2006 maka IIS menjadi kelas reguler dengan satu konsentrasi Pekerjaan Sosial. Seiring berjalan waktu, proyek pengembangan jurusan — dipengaruhi oleh konsep integrasi-interkoneksimaka tahun 2009 lahirnya konsentrasi IImu Perpustakaan dan Informasi (IPI) pada program IIS. Kemudian, pengaruh tersebut membawa dampak pada proses pembelajaran di kelas ketika dosen memberikan materi kepada mahasiswa.

Dari beberapa karya di atas, sebagai sebuah landasan pustaka dapat kita jadikan pedoman untuk model pembelajaran dengan memakai paradigma integrasi-interkoneksi. Namun, perlu digaris bawahi bahwa sejauh ini karya-karya tersebut belum ada yang lebih spesifik menjelaskan tentang aplikasi dari paradigma pengklasifikasian ilmu pengetahuan dengan term integrasi-interkoneksi ke dalam proses pembelajaran di kelas. Artinya, sampai saat ini belum ada karya yang lebih spesifik menjelaskan keterkaitan antara rumpun IImu Sosiologi dengan Humaniora ke dalam bentuk aplikasi pembelajaran.

Secara sosio-historis, paradigma integrasi-interkoneksi merupakan ciri dari tradisi dan sifat natural dari keilmuan itu sendiri yang dalam Islam telah muncul dan berkembang sejak periode klasik masa keemasan Islam. Masa kekhalifahan Daulah Abbasiyah di Baghdad telah menghasilkan para ilmuwan Muslim dalam berbagai bidangnya dengan tidak melakukan dikotomi dalam pembangunan keilmuannya. Para ilmuwan Muslim, seperti 
al-Farabi, Ibnu Sina, Ibn Arobi, al-Suhrawardi, al-Ghazali dan yang lainnya bahkan membuktikannya dengan memadukan antara tradisi filsafat Yunani dengan teologi, tasawuf dan ajaran-ajaran Islam lainnya. Lahirnya teosofi dan falsafah wahdatul wujud dalam filsafat al-Farabi dan Ibnu Arobi, filsafat Isyraq (iluminasi) dalam tradisi filsafat Suhrawardi, integrasi fiqih, yang bercirikan eksoterik, dengan tasawuf, yang bercirikan esoterik dalam konsep al-Ghazali merupakan beberapa fakta bahwa integrasi-interkoneksi telah lama berkembang dalam keilmuan dan peradaban Islam sejak masa klasik. Di samping itu, mereka juga banyak menguasai disiplin keilmuan yang berbeda, karena dalam pandangan mereka ilmu berasal dari satu hakikat tunggal yaitu Tuhan. Sedangkan secara sosiologis, mereka pada umumnya lahir dari berbagai wilayah dan tradisi keilmuan yang berbedabeda, sehingga membentuk corak keragaman namun dalam kesatuan (unity in diversity).

Oleh karena itu, secara sosio-historis paradigma integrasi-interkoneksi memiliki relevansi faktual dan konsepsional yang kuat. Sehingga akar historsitasnya telah terbangun dari berbagai latar-belakang tradisi keilmuan; Yunani, Persia, Romawi, India dan yang lainnya. Demikian juga tradisi keagamaan, seperti Yahudi, Kristen dan Islam. Di era modern, tuntutan wacana-wacana pengembangan keilmuan melalui pelbagai paradigma, pendekatan dan perspektif dengan beragam istilahnya mewarnai khasanah intelektual keislaman. Di antara paradigma tersebut adalah integrasi-interkoneksi dalam mengkaji pelbagai disiplin keilmuan, termasuk dalam kajian ilmu-ilmu keislaman (Islamic studies). Dalam konteks UIN Sunan Kalijaga, awalnya, tawaran integrasi-interkoneksi bersamaan dengan konversi dari IAIN menjadi UIN pada masa kepemimpinan Prof. Amin Abdullah.

Sebelum Amien Abdullah, di IAIN—sebelum menjadi UIN—sendiri, sebenarnya sudah dimulai dari tradisi masa Prof. Mukti Ali, yang memperkenalkan pengembangan metode memahami Islam. Dalam pandangannya, memahami Islam paling tidak ada tiga pendekatan yang dapat dikembangkan yakni naqli (tradisional), kedua aqli (rasional) dan ketiga pendekatan secara kasyfi (mistis). ${ }^{13}$ Selain kedua tokoh di atas, tokoh lain yang membahas tentang ilmu-ilmu ke-Islaman ada Nurcholis Madjid yang menawarkan gagasan tentang teologi pluralistik. ${ }^{14}$ Dalam pandangannya, memahami Islam tidak bisa hanya satu arah rumpun ilmu akan tetapi harus secara terbuka dengan lugas menerima ilmu-ilmu baru 
yang mana dapat disaring menjadi pemahaman baru. Sehingga tujuan akhir dari adanya dealektika tersebut ketika melihat persoalan atau konflik sosial secara lugas dapat memahami Islam secara inklusif. Dalam konteks ini, mazhab Jakarta dengan mazhab Yogyakarta dalam memahami studi Islam telah meletakkan pandangan yang sama yakni dari kaidah secara terbuka dan dapat menfilter kajian-kajian ke-Islaman yang lebih bermakna sesuai dengan kebutuhan masyarakat Indonesia yang saat ini mutlak membutuhkan kebaruan dan menjadi solusi atas persoalan sosial.

Ditinjau dari sisi ini, maka lahirnya sebuah tawaran paradigma "baru" dalam memahami Islam ini, ${ }^{15}$ tidak terpisah dari konteks konversi status IAIN ke UIN di atas, yang berarti juga menuntut adanya pengembangan ilmu-ilmu keislaman yang "dikawinkan" dengan ilmu-ilmu umum, sehingga tidak terjadi dikotomi keilmuan dalam kajian ilmu-ilmu keislaman. IAIN sendiri, yang berarti sebuah institut Islam hanya mengkaji ilmu-ilmu keislaman, ketika konversi menjadi UIN, yang berarti sebuah universitas Islam, yang selain mengkaji ilmu-ilmu keislaman juga ilmu-ilmu umum, sehingga terbuka lahirnya fakultas-fakultas baru non keagamaan. Keterbukaan terhadap fakultas-fakultas baru termasuk jurusan-jurusan baru, seperti sains dan teknologi, fisika, kimia dan ilmu-ilmu humaniora, secara bersamaan tentu menuntut lahirnya paradigma yang "baru" pula, sehingga perkembangan universitas Islam, hasil konversi dari IAIN ke UIN, tidak sekedar perubahan infrastruktur (fisik dan struktur bangunan/ gedung), tetapi juga perkembangan supra strukturnya dalam dataran konseptual paradigmatik. Di sinilah relevansi paradigma integrasi interkoneksi itu dalam konteks konversi IAIN ke UIN.

Dalam konteks keilmuan yang lebih luas lagi, secara substansial paradigma integrasi interkoneksi, seperti dijelaskan oleh Prof. Amin Abdullah mengonsepsikan hubungan-hubungan pelbagai keilmuan, antara ilmu-ilmu keislaman dan ilmu-ilmu umum, dalam framework jaring labalaba. ${ }^{16}$ Integrasi keilmuan menuntut kesatuan dan tidak ada lagi dikotomi antara ilmu-ilmu keislaman denagan ilmu-ilmu umum dalam wilayah kajian keilmuan. Sedangkan interkoneksi mengindikasikan perlunya "dialog" dan "saling sapa" antara kedua ilmu tersebut, baik dalam perspektif maupun kaitan pengkajiannya. ${ }^{17}$ Dengan paradigma integrasi-interkoneksi kajiankajian keislaman memiliki ranah keuniversalannya, relevansi, dan sinkronisasi dengan ilmu-ilmu umum yang lainnya. Kajian ilmu-ilmu keislaman tidak lagi hanya melihat pada sisi yang sempit seperti disiplin 
keilmuannya saja, tetapi juga problem ilmiah akademiknya, dihubungkaitkan dan direlevansikan dengan kaidah-kaidah serta teori-teori yang terkait dengan problem ilmiah tersebut. Sebagai contoh, kajian dalam Fiqih Munakahat, tidak hanya dilihat dari disiplin keilmuan fiqih saja, tetapi ia berkait-kelindan dengan ilmu sosiologi, antropologi, sejarah dan filsafat hukum Islam. Demikian juga dengan kajian konflik Sunni-Syi'ah dalam kajian sejarah Islam. la bukan semata-mata milik kajian ilmu sejarah, tetapi terkait dengan teologi, mengenai keyakinan dan masing-masing doktrinnya, sosiologi, dalam kaitan teori konflik dan konteks masyarakatnya, antropologi dalam kaitan perilaku masing-masing kelompok berdasarkan konsep teologi dan ideologinya, dan psikologi, mengenai ketertindasan kelompok Syi'ah dan hegemoni massive kelompok Sunni dalam sejarah dan peradaban Islam klasik.

Paradigma integrasi interkoneksi dengan penjelasan dataran konsepsi dan paradigmatik di atas, perlu juga untuk dilihat dari dataran empiris dan aplikasinya dalam proses pembelajaran dan pengayaan kurikulum di Universitas Islam Negeri Sunan Kalijaga, khususnya dalam wilayah fakultas dan program studi. Hal ini karena integrasi-interkoneksi telah menjadi ikon UIN Sunan Kalijaga sebagai konsekuensi dari ranah konsepsionalparadigmatik yang telah disosioalisasikan, khususnya di lingkungan UIN Sunan Kalijaga Yogyakarta. Oleh karena itu, penelitian ini mencoba untuk melihat ranah aplikasi integrasi-interkoneksi dalam konteks Program Studi Interdisciplinary Islamic Srudies (IIS), Pascasarjana UIN Sunan Kalijaga Yogyakarta.

Relevansi meninjau aplikasi paradigma integrasi-interkoneksi dalam konteks Prodi IIS ini selain memandang pentingnya paradigma tersebut, juga karena secara faktualnya Prodi IIS sendiri memiliki dua konsentrasi yang secara rumpun keilmuanya berbeda, yakni Konsentarasi Pekerjaan Sosial dengan rumpun IImu Sosiologi dan IImu Perpustakaan dan Informasi (IPI) dengan rumpun IImu Humaniora. Sesuai dengan nomenklatur BAN/ PT Kemenag RI Pekerjaan Sosial masuk ke dalam rumpun keilmuan sosiologi, ia kemudian menjadi konsentrasi dalam prodi IIS. Sedangkan, IPI masuk dalam rumpun IImu Humaniora dengan nama konsentrasi IPI dalam prodi yang sama. Meskipun antara Peksos dengan IPI secara keilmuan berbeda, akan tetapi keduanya memiliki hubungan keterkaitan jika saja paradigma integrasi-interkoneksi benar-benar diaplikasikan dalam proses pembelajaran dan kurikulum di Prodi tersebut. 


\section{JUSTIFIKASI IMPLEMENTATIF METODE PENGAJARAN}

\section{Implementasi Nilai-Nilai Keislaman}

Konsep integrasi-interkoneksi merupakan sebuah pendekatan baru dalam wacana keilmuan, khususnya setelah terkotak-kotak antara ilmu agama dengan ilmu umum. Sehingga kelompok-kelompok masyarakat yang terwadahi oleh payung organisasi membuat ideologisasi bagi kadernya, sehingga hal ini kemudian menyebabkan adanya 'truth claim' diantara kelompok tadi. Namun, seiring dengan perkembangan waktu dan lahirnya pemikir-pemikir Islam Indonesia (cendikiawan muslim), sebut saja Prof. Dr. Amin Abdullah mantan Rektor UIN Sunan Kalijaga memperkenalkan istilah integrasi-interkoneksi kepada khalayak khususnya para civitas akademik kampus.

Lahirnya konsep integrasi-interkoneksi tersebut membawa angin segar bagi pekembangan pemikiran Islam, khususnya bagi civitas akademik UIN Sunan Kalijaga yang dapat membawa ke arah kemajuan keilmuan dan peradaban. Walaupun sontak pada awal penggagasan konsep itu banyak pihak tidak sepakat bahkan cacian dan ejekan silih berganti. Dengan hati kuat dan tekad yang mantap untuk menatap kemajuan pemikiran Islam, maka lambat laun konsep tersebut dapat diterima oleh masyarakat.

Konsep itu tidak hanya dapat diterima sebagai dasar pengembangan kurikulum pada tingkat perguruan tinggi Islam, jauh daripada itu konsep Integrasi-Interkoneksi banyak diadopsi dalam peletakan konsep dasar untuk pengembangan kurikulum pendidikan menengah ke bawah-Madrasah Aliyah, Tsanawiyah, Ibtidaiyah dan Raudattul Atfal. Ini terbukkti, wujud dari dasar integrasi-interkoneksi itu dengan adanya perpaduan antara ilmu agama dan umum diberbagai instansi sekolah di bawah naungan Kementerian Agama.

Ini merupakan sebuah prestasi bagi UIN Sunan Kalijaga, karena konsep pengembangan keilmuan ini dapat bermanfaat bagi pengembangan pemikiran Islam. Tentunya prestasi ini dimanfaatkan oleh semua stakeholder pemegang kebijakan dilingkungan kampus UIN untuk mengembangkan dan mengimplementasikan pada kurikulum konsep integrasiinterkoneksi itu sendiri. Maka dari itu, Interdisciplinary Islamic Studies (IIS) sebagai bagian dari UIN mampu menerapkan konsep integrasi-interkoneksi itu tidak hanya wujud administratif, dalam aplikasi proses pembelajaran pun telah banyak diimplementasikan. Hal ini diperjelas dari hasil kutipan wawancara sebagaimana berikut ini: 
Dalam proses pembelajaran saya mencoba mengimplementasikan nilai-nilai konsep integrasi-interkoneksi. Terutama nilai-nilai keislaman dalam proses pembelajaran di kelas. Selain itu, saya juga mengimplementasikan pendekatan integrasi tersebut tidak hanya tentang keislaman, jauh dari itu juga menerapkan aplikasi nilai-nilai budaya lokal, antara teori dan praktik juga. Jadi, integrasi antara Islam dan peksos, peksos dan budaya lokal, dan sesekali juga budaya global dan juga antara teori dan praktik. Contoh untuk kajian global adalah isu-isu kontemporer dalam pengkajian pekerja sosial yang membahas mengenai perempuan, trafficking, ini tidak hanya dari dalam tetapi juga dari sisi global, sisi perempuan dari luar, sisi globalisasi, kemudahan orang untuk keluar, meskipun ada budaya lokal yang dibahas mengenai kemiskinan dan sebagainya, juga ada sisi ekonomi dari segi kemiskinan tadi, sisi security politik, tidak adanya jaminan security bagi masyarakat Indonesia, policy tidak bertindak dengan baik, tidak mengayomi, membiarkan dan juga pengawasan yang kurang. ${ }^{18}$

Cerita pengalaman di atas, membuktikan bahwa nilai-nilai ke-Islaman sebagai basic pengembangan keilmuan, telah mampu dikembangkan dan dieksplorasi oleh semua staff pengajar pada program studi IIS itu sendiri. Ini terbukti ketika dosen memberikan materi kuliah kepada mahasiswa dengan melihat dua aspek penting yaitu antara teori-teori yang disampaikan dengan aplikasi praktik di lapangan sangat erat memperhatikan esensi nilai dari konsep integrasi-interkoneksi.

Namun, disisi lain ada pula dosen yang masih mengimplementasikan hanya interkoneksi saja. Hal ini dilakukan karena masih minimnya literatur pengembangan kurikulum integrasi ilmu yang diampu oleh salah satu dosen. Tapi secara esensial saling sapanya antara ilmu umum dengan ilmu agama, semisal, adanya hadits dan ayat-ayat Alquran sebagai dasar framework bagi bahan diskusi yang diberikan kepada mahasiswa dapat diaplikasikan dengan baik. Hal ini terbukti dengan yang disampaikan apa adanya oleh salah satu pengampu mata kuliah pada konsentrasi Peksos, sebagaimana berikut ini:

Saya mengajar di Pascasarjana itu mata kuliah kebijakan-kebijakan sosial di Indonesia. Eeea, saya melakukan interkoneksi ya, karena saya belum memiliki kapasitas untuk melakukan integrasi, tetapi saya melakukan interkoneksi. Semisal begini, ketika saya mengajarkan sesi perencanaan sosial, saya sampaikan dalil, hadits, maupun ayat Alquran tentang apa itu pentingnya perencanaan, kemudian ketika sesi evaluasi kebijakan sosial dalam mata 
kuliah itu, saya juga sampaikan bahwa ada hadits tentang 'muahtabah', ini kan bagian interkoneksi ya, artinya ketika mempelajari kebijakan dalam perencanaan sosial, maka mahasiswa juga akan tahu oooww, Islam punya kesan terkait dengan evaluasi, terkait dengan perencanaan, terkait dengan konsen-konsen yang dipelajari. Kalau secara pribadi, saya memang masih menerapkan interkoneksi saja, belum sampai pada integrasi, karena masih saya pelajari terkait dengan konsen studi pengajaran saya. ${ }^{19}$

Dari hasil kutipan wawancara di atas, kita dapat melihat bahwasanya dosen pengampu mata kuliah telah mampu menerapkan konsep interkoneksi atau saling tegur sapa antara nilai-nilai Islam dengan mata kuliah kebijakan-kebijakan sosial di Indonesia. Hemat peneliti, implementasi nilainilai ke-Islaman merupakan sebuah penjelasan sederhana yang mampu dikembangkan menjadi bagian luas tentang pengayaan materi yang disampaikan. Tentunya, memperhatikan nilai-nilai integrasi-interkoneksi itu sendiri.

\section{Implementasi Integrasi Lintas Disiplin Ilmu}

Disiplin ilmu bagi sebuah program studi menjadi sangat penting. Ini merupakan kunci bagi arah dan tujuan dari program studi itu sendiri. Tapi dalam proses pengaplikasian pola pengajaran, paling esensial sebuah program studi harus memiliki dasar kurikulum yang jelas. Dalam pada itu, di program studi IIS; IPI dan Peksos, telah memiliki pemahaman secara mendasar untuk diaplikasikan oleh semua staff pengajar, yaitu integrasi lintas disiplin ilmu. Semisal, dalam mata kuliah isu-isu kontemporer pada konsentrasi pekerjaan sosial, saling sapa antara ilmu satu dengan yang lain sarat ditemukan dalam berbagai sistem perkuliahan. Sebagaimana diperjelas hasil kutipan wawancara berikut ini:

Jadi, integrasi tidak hanya dari sisi tadi yang sudah disebutkan tetapi juga dari segi politik, ekonomi, hukum, dan sebagainya yang melingkupi atau dari sebab adanya kejadian trafficking. Integrasi dalam hal ini tidak hanya berbicara mengenai Islam dan non Islam tetapi juga lintas antar keilmuan seperti halnya tadi disebutkan, dan juga integrasi antara teori dan praktik. ${ }^{20}$

Pandangan tadi, mamiliki arti yang cukup luas dalam proses pengaplikasian paradigma integrasi-interkoneksi di UIN Sunan Kalijaga. Demikian ini merupakan sebuah pola relasi antara stakeholders dengan staff pengajar 
pada program IIS menjadi sangat penting untuk tetap memberikan pemahaman integrasi-interkoneksi. Memang saat ini banyak dijumpai dosen yang mengajarkan keilmuan kepada mahasiswa sarat ditemukan masih belum menerapkan paradigma utuh dari integrasi-interkoneksi.

Maka dari itu masih ditemukan dalam proses pembelajaran di kelas ada sebagian dosen hanya memberikan ceramah atau diskusi kelas menggunakan interkoneksi saja. Pola ini dilakukan karena tidak semua mata kuliah yang dosen ampu memiliki konsep integrasi. Karena pada dasarnya paradigma integrasi-interkoneksi merupakan peleburan antara ilmu agama dengan ilmu umum. Sebagaimana hasil kutipan wawancara berikut ini:

Integrasi-interkoneksi yang saya pahami adalah peleburan antara ilmu umum dan ilmu agama, dalam rangka untuk kesejahteraan bersama. Karena selama ini kan terjadi dikhotomi ini ilmu agama, ini ilmu umum tidak adanya saling sapa sehingga dengan adanya konsep integrasi-interkoneksi ini akan saling terkait, saling membantu, saling berhubungan dan saling memberikan kontribusi, dari kedua ilmu ini tidak terjadi pengkotak-kotakan, karena sebagaimana kita tahu memang ada persoalan yang tidak bisa selesai hanya dengan ilmu-ilmu agama. Dengan adanya dimensi dengan dua bidang tadi, bisa menjadi solusi untuk pengembangan ilmu dan aplikasi pemanfaatannya. ${ }^{21}$

Kutipan tersebut, mempertajam daya analisis peneliti dalam memahami sejauh mana aplikasi dosen pengampuh mata kuliah dapat menjelaskan paradigma integrasi-interkoneksi dalam proses pengajaran. Artinya, dosen pengampu mata kuliah sedikit banyak telah memahami esensi dari paradigma itu tadi. Sehingga dapat kita interpretasikan bahwa integrasi lintas disiplin ilmu telah digunakan sebagai dasar pengembangan sistem akademik dan perkuliahan di kelas.

Dosen lain, menjelaskan pula bahwa pemahaman paradigma integrasiinterkoneksi itu penyatuan dan peleburan ilmu agama dengan ilmu umum atau jamak kita temukan proses saling tegur dan sapa. Mengingat bahwa pengkotan ilmu dalam proses transformasi gagasan sering menjadi dikotomi antara ilmu agama dengan umum ketika menyangsikan wacana sekulerisasi, islamisasi ilmu dan lain-lain. Untuk itu, diperjelas oleh salah satu dosen sebagaimana hasil kutipan wawancara berikut ini:

Menurut saya integrasi-interkoneksi itu kan dua kata yang berbeda, yang dari kedua istilah tersebut disatukan atau peleburan. Pertama, integrasi adalah dua rumpun keilmuan yakni antara ilmu agama dan ilmu umum itu menyatu. 
Apakah penyatuan itu berdasarkan nash-nash Alquran atau Hadits, disekulerisasikan kah atau diislamisasikan. Sedangkan, interkoneksi itu berasal dari kata koneksi yang artinya 'menyapa ya', jadi berhubungan. Oleh karena itu, interkoneksi itu tidak menyatu tetapi melebur dengan adanya komunikasi diantara keduanya, antar saling sapa dan jumpa. Nah mungkin, sesuai dengan perkataan seseorang, tetapi saya lupa namanya, integrasi-interkoneksi itu seperti ini misalnya, kalau interkoneksi itu seperti 'Gado-Gado', jadi dalam 'Gado-Gado' itu kita tahu, oww ini kacangnya, ini timunnya, ini sayurnya, masih bisa dipetakan pemetaannya. Namun, integrasi itu seperti roti, di dalam roti itu ada telor, ada tepung, ada bumbu, tetapi kita tidak bisa menguraikan, tapi menjadi satu itu integrasi. Tetapi, interkoneksi seperti sesuatu hal yang baru, kita bisa pilah mana yang penting mana yang tidak penting sekiranya menurut kita. ${ }^{22}$

Interpretasi hasil wawancara itu, dosen menganalogikan bahwa proses pembelajaran integrasi itu umumnya dengan mengambil referensi atau bahan kajian lain yang sekiranya di dalam pengimplementasian keilmuan pada proses pembelajaran mampu menerangkan dengan ragam perspektif. Semisal, analogi 'Gado-Gado', tentu ini membuat kita memahami ragam perspektif yang muncul pada setiap persoalan yang ada. Bahkan ditengah persoalan 'kejumudan' berpikir dan kemandegan bertindak karena dipengaruhi oleh pola paham ilmu truth claim kadangkala pemikiranpemikiran hasil output mahasiswa terkooptasi dalam satu bidang ilmu agama saja. Demikian ini akan sangat berbahaya jika seorang dosen tidak mampu mengkaitkan ragam perspektif ilmu satu dengan ilmu lainnya.

\section{Aplikasi dalam Satuan Acuan Pembelajaran}

Banyak ragam pemahaman dosen mengenai paradigma integrasiinterkoneksi yang telah dieksplorasi. Kiranya sebagai landasan awal sudah mengetahui pandangan umum tentang apa yang disampaikan oleh dosen. Sehingga aplikasi dalam hal teknis menjadi menarik melihat kembali dalam beberapa aspek penting yang perlu dikaji. Sebagaimana interpretasi peneliti pada kajian ini ada beberapa unsur penting yang dapat diekplorasi lebih lanjut, berdasarkan hasil koding data dan display data, dalam proses aplikasi integrasi-interkoneksi dosen telah menerapkan ke dalam hal teknis dengan membuat acuan pada Satuan Acuan Pembelajaran (SAP), melakukan evaluasi individu, dan aplikasi dalam diskusi di kelas. Demikian ini dapat dijelaskan sebagaimana hasil interpretasi di bawah. 
Suatu output pendidikan dapat dikatakan bermutu, jika proses pembelajaran di kelas secara menarik dan menantang, sehingga nahasiswa dapat belajar sebanyak mungkin melalui proses dealektik dan dialogis antara mahasiswa dengan dosen. Proses ini akan membuahkan hasil yang bermutu dan dengan harapan dapat menjadi sebuah acuan kerangka berpikir bagi pembangunan di masa mendatang. Untuk mewujudkan demikian itu perlu efisien dalam penyusunan Satuan Acuan Pembelajaran (SAP) yang disusun oleh dosen, kemudian bisa dilaksanakan dengan sebaikbaiknya ketika proses pembelajaran berlangsung.

Dengan begitu, aplikasi ilmu dalam proses transformasi ide dan gagasan pada mahasiswa bisa diharapkan mampu menopang framework secara berkesinambungan. Ini merupakan cita-cita yang ingin dicapai dalam program studi IIS ketika seorang dosen mampu mengintegrasi keilmuan umum dengan Islam ke dalam perspektif ilmu IPI dan Peksos secara berskala. Kualitas ini dapat terlihat jika semua dosen menerapkan paradigma integrasi-interkoneksi ke dalam SAP yang disusun di awal sebelum proses pembelajaran. Sehingga selama proses pembelajaran berlangsung mahasiswa dapat dengan mudah dan diharapkan bisa mengembangkan acuan pembelajaran yang sistematis dan terorganisir. Tentu dengan referensi-referensi buku atau lainnya yang dikontekskan kebaruan. Semisal dalam pengkajian mata kuliah Pendekatan Studi Islam secara penjelasan dapat diketahui lebih awal sebagai acuan pengembangan akademik. Semisal, dalam SAP dosen menjelaskan seperti ini:

Islam sebagai ajaran (wahyu) memang bersifat normatif yang memiliki kebenaran universal dan mutlak, namun ketika ajaran-ajaran Islam yang normatif tersebut berinteraksi dengan konteks zaman (sejarah) dan pemahaman manusia, maka Islam memuat aspek yang bersifat relatif dan temporal. Karena itu, terjadi perbedaan antara ajaran yang terkandung di dalam teks (nash) dengan pemahaman manusia terhadap nash maupun manifestasinya dalam konteks historis, atau antara das sein dan das sollen. Perbedaan ini dapat dilihat dalam berbagai bentuk, baik dari konteks zaman (waktu) maupun makan (tempat). ${ }^{23}$

Penjelasan makna ke-Islaman di atas merupakan deskripsi awal dalam implementasi paradigma integrasi dan interkoneksi yang dikontekskan dengan satuan pembelajaran. Maka penjelasan lebih spesifik dosen mengeksplorasi mengenai rencana pembelajaran ke dalam bentuk tujuan 
dan capaian dari perkuliahan yang akan berlangsung. Ini kemudian diinterpretasikan dan diberikan kepada mahasiswa untuk dijadikan pedoman diskusi selama satu semester ke depan. Tentunya, demikian itu dispesifikasikan ke dalam bentuk kata-kata dalam SAP kemudian diberikan kepada mahasiswa untuk dipahami, agar mahasiswa pun mampu mengimbangi perkuliahan dengan jelas dan sesuai dengan konteks materi yang ada. Sebagai contoh sebagaimana dijelaskan yang dikutip dari SAP dosen berikut ini:

Mata Kuliah Perspektif Kesejehateraan Sosial dalam Alquran, sebagaimana namanya menguraikan ayat-ayat Alquran yang mengandung dan mendorong terciptanya kesejahteraan sosial dan masyarakat. Kajian tafsir ini, bukan semata-mata agar menjadi landasan normatif bagi terwujudnya kesejahteraan di masyarakat, tapi juga mengurai bagaimana Alquran, secara metodologis mengupayakan terwujudnya kesejahteraan tersebut. Dengan kata lain bagaimana "pandangan atau wawasan" Alquran tentang kesejahteraan sosial dan bagaimana pesan-pesan Alquran untuk mewujudkan kesejahteraan tersebut? Menurut Alquran, strategi dan langkah apa saja yang harus ditempuh untuk mengantar menuju masyarakat sejahtera?Apakah langkah-langkah yang dipesankan Alquran bersifat sukarela (charity) atau bersifat sistemik? Masyarakat sejahtera seperti apa yang dicita-citakan Alquran? Dan apa ukuran kesejahteraan dalam Alquran serta apa saja dimensi kesejahteraan tersebut. ${ }^{24}$

Selain SAP sebagai aplikasi paradigma integrasi dan interkoneksi dalam proses pembelajaran, dosen harus menerapkan paradigma integrasi dan interkoneksi dalam kegiatan pembelajarannya. Dosen juga diberi tugas menyusun sillabi dan RPKPS (Recana Program Kegiatan Perkuliahan Semester), termasuk bahan ajar pada mata kuliah yang diampunya. Tetapi latar belakang pendidikan dan ketersediaan referensi yang dimiliki dosen, sangat menentukan kualitas pengajaran ketika di kelas, baik yang berhubungan dengan substansi materi pokok, substansi materi ilmu lain yang akan dijadikan bahan integrasi dan interkoneksi, serta substansi paradigma integrasi-interkoneksi itu sendiri. Persoalan ini sebagaimana diperjelas oleh dosen pengampu mata kuliah di IIS berikut:

Jadi menurut saya adalah integrasi-interkoneksi jangan hanya di pandang dan dipahami hanya Islam dan non Islam, dalam Islam pun ada integrasi interkoneksi, yaitu pemahaman tafsir itu juga harus bervariasi. Misalnya, tafsir mengenai nikah lebih dari satu, itu mau ditafsirkan seperti apa, kita 
mau berpihak kepada siapa, kalau kita berbicara perempuan dan perlindungan perempuan, maka itu harus ditafsirkan berdasarkan keadilan sosial gender. Bahwa nikah satu itu lebih utama dan diutamakan daripada nikah lebih dari satu. Karena untuk mencapai keadilan itu sulit, keadilan itu mungkin bisa hanya ditaraf materi, waktu atau tempat. Tapi keadaan dilandasi sisi keadilan sosial, perhatian dari sisi kasih sayang hal itu tidak mungkin bisa dibagi dan dapat berlaku adil. Sebenarnya lebih dari satu itu darurat dan sangat lebih darurat, daripada yang jauh, jadi dalam istilah ushul figh itu ada hal mencari darurat yang lebih kecil atau mudarat yang lebih kecil, atau efek negatif yang paling kecil. ${ }^{25}$

Walaupun masih ada juga beberapa dosen dalam proses pembelajaran masih tidak menggunakan paradigma tersebut. Persoalan yang melatarbelakangi kurang terealisirnya paradigma integrasi-interkoneksi dalam pendidikan dan pengajaran itu disebabkan oleh latar belakang pendidikan dosen yang kurang mendukung integrasi-interkoneksi baik pada aspek substansi keumuan, substansi paradigma integrasi-interkoneksi, maupun masalah teknis-metodologis. Disamping itu berbagai pembekalan dan prasarana seperti perpustakaan ke arah terlaksananya pendidikan berparadigma integrasi-interkoneksi belum benar-benar efektif.

\section{Aplikasi dalam Dikusi Kelas}

Proses pembelajaran di kelas menjadi menarik dengan pengembangan integrasi dan interkoneksi. Karena itu, semua dosen semestinya sudah menerapkan paradigma ini. Tetapi peneliti dalam hal ini masih juga menemukan ada sebagian dosen yang belum mengaplikasikan paradigma tersebut ke dalam pembelajaran. Tapi, ada juga dosen yang sudah mengaplikasikan hanya sebatas interkoneksi saja. Alasan dosen ini karena masih banyak rujukan akademik dan pemahaman dosen mengenai bahan pengajaran yang dia ampuh, menurutnya masih dalam proses penjajakan integrasi ilmu. Jadi belum seutuhnya mengaplikasikan integrasi-interkoneksi, juga diperjelas berdasarkan hasil kutipan berikut:

Jadi itu, saya melakukan integrasi itu dalam bentuk eee strateginya pembelajarannya. Jadi misalnya saya perkenalkan ada hadits, misalnya juga saya mengajar peksos industri ada sesi tentang upah minimum, saya sampaikan Hadits, 'bayarlah upah buruhmu sebelum kering keringatnya', nah itu kan bagian dari interkoneksi, artinya dalam Islam juga menekankan perlindungan sosial bagi buruh apalagi dalam konteks keilmuan ya. ${ }^{26}$ 
Lain halnya, dosen dikonfirmasi ketika proses pembelajaran di kelas, secara umum sudah menerapkan paradigma integrasi-interkoneksi. Ini terekam dalam proses penyampaian penafsiran makna keilmuan, seperti hasil kutipan wawancara sebagaimana berikut:

Maka dalam Islam pun harus ditafsirkan sesuai dengan semangat keadilan sosial yang itu menjadi inti ajaran Islam. Jadi tidak sekedar perspektif fundamental Alquran dan disandingkan dengan prinsip peksos, hal itu selesai, tidak demikian. Karena dalam Islam sendiri ada teks dan konteks, dimana hal ini saling berkaitan dan ada tafsir yang lebih berpihak kepada orang miskin, orang marginal perempuan, itu yang lebih diutamakan. Karena banyak tafsir yang bias gender, bias laki-laki, karena fuqoha semuanya laki-laki, karena munfasir semuanya laki-laki, dan konteks historinya partiarkhal budayanya, jika hal ini kita gali lebih jauh dari sirat Nabi, itu masih bisa kita tafsirkan kearah sana, yaitu Islam yang berkeadilan. ${ }^{27}$

Secara umum semua narasumber dalam penelitian ini ketika dikonfirmasi mereka telah memakai paradigma integrasi-interkoneksi dalam proses pembelajaran. Namun, tidak secara utuh semuanya memakai paradigma itu. Banyak hal yang menyebabkan mengapa ada dosen yang belum menggunakan. Tetapi bila dilihat memang belum seutuhnya aplikasi paradigma integrasi-interkoneksi itu diejawantahkan ke dalam bentuk pemahaman kolektif dosen. Maka untuk menyiasati demikian ini perlu IIS melaksanakan workshop kepada semua dosen baik dosen tetap, dosen LB, maupun dosen dari luar atau praktisi.

Dibutuhkan pemahaman kolektif ini paling tidak ketika menyampaikan diskusi di kelas tentang bahan ajar yang disampaikan dosen dan mahasiswa dapat mensinergiskan pemahaman mengenai satu topik yang dibahas, kemudian pengembangan pemikiran dari berbagai perspektif khususnya interpretasi pemahaman Islam dengan keterkaitannya dengan ilmu umum yang dibawa. Semisal, IIS; Pekerjaan Sosial, secara umum teori-teorinya dari barat, tetapi kemudian bila dosen paham dengan kondisi ini, harus sudah diintegrasikan materi tersebut ke dalam satu wadah integrasiinterkoneksi. Tidak kemudian western ansih tentang apa yang disampaikan ketika berada di dalam kelas.

\section{Evaluasi Terhadap Satuan Pembelajaran}

Evaluasi mengenai sistem pengajaran pada Prodi IIS, banyak dosen 
melakukan kritik terhadap adanya dua konsentrasi rumpun ilmu yang berbeda, yaitu antara IPI dan Peksos. Secara umum semua orang tahu IIS dari dua rumpun ilmu berbeda itu alasan pragmatis. Tetapi menjadi titik tekan itu menjadi bagus ketika dikelola dengan maksimal tanpa harus ada dikotomi di dua konsentrasi tersebut. Ini sebagaimana disampaikan oleh narasumber penjelasan berdasarkan hasil kutipan berikut:

Hal ini memang di IIS; antara IPI dan Peksos, studi tentang pemaksaan wadah tetapi pragmatis. Walaupun pemaksaan tetapi itulah yang terbaik. IIS pada desain awalnya memang agar social work dapat masuk di IAIN waktu itu. Karena ada kata 'I' (Islamic Studies) termasuk agama Islam, maka harus ada sisi keislaman. Maka kemudian dinamakan IIS (Interdisciplinary Islamic Studies), studi Islam yang interdisipliner, tetapi tetap judul utamanya studi Islam. Interdisipliner yakni antar disiplin, jadi menjembatani Social Work, maka dapat dikatakan bahwa hal ini jembatan yang bagus, kreatif, untuk memasukan Social Work ke dalam Islamic Studies. Sekarang sebetulnya ketika IAIN menjadi UIN, hal itu sudah tidak jadi masalah kalau tanpa IIS pun tidak masalah, tetapi hal ini sudah terlanjur masuk ke dalam dokumen negara. ${ }^{28}$

Namun, bisa saja ke depannya bisa didesain ulang namanya tidak IIS, namanya misalnya Social Work atau kesejahteraan sosial sehingga bisa terkoneksi dengan S1-nya. Tetapi itu juga menjadi masalah dilihat dari background calon mahasiswa baru ketika rumpunnya menjadi Social Work, jadi enggan masuk bila tidak berlatarbelakang Kesejahteraan Sosial pada waktu S1-nya, semisal PMI nanti enggan masuk, tetapi saat ini tidak jadi masalah, hanya nanti kurikulumnya lebih dinamis. Social Work merupakan ilmu yang lengkap mulai dari A sampai Z adanya-Mikro, Mezzo dan Makro. Maka ada kesulitan, IIS mau dibawa kemana, mau spesialisasi Mikronya, Mezzonya, atau Makronya atau bahkan tidak kemana-mana jadi 'Gado-Gado', sehingga nanti semuanya tidak mendalam. Akhirnya kebutuhan pasar seperti apa dan calon mahasiswanya nanti seperti apa yang betul-betul dibutuhkan.

Melihat peta di atas, kiranya perlu melakukan evaluasi satuan pembelajaran dengan mencoba menanyakan persepsi alumni. Karena kebutuhan riil dalam Prodi sejatinya berada pada pasar kerja yang dapat menampung kebutuhan background studi IIS itu sendiri. Demikian ini disampaikan oleh salah satu narasumber sebagaimana penjelasan dari kutipan wawancara berikut: 
Mungkin juga perlu juga evaluasi alumni yang selama ini. Jadi alumni IIS itu kemana mereka dan apakah mereka menganggap bahwa ilmu yang di dapat dari IIS kemarin itu menunjang kebutuhan mereka dan pekerjaan mereka. Kalau tidak apa yang perlu ditambahkan, kan begitu. Tapi itu perlu 'diramu', karena nanti berbagai macam input kan. Selama ini, semisal kemarin saya bertemu orang dan konsultasi kepada saya, dia diterima di dua tempat, apakah ke Bandung S2 ke (STKS) atau S2 ke UIN. Saya hanya memberikan alternatif kepada mahasiswa saya, artinya kembali kepada dirinya sendiri, kamu nanti mau jadi apa, mau jadi praktisi atau jadi dosen di sekolah tinggi Islam-UIN, STAIN, atau yang lain. Jika alternatif pilihanya ingin menjadi dosen maka masuklah ke UIN-IIS, tetapi bila ingin menjadi praktisi maka masuklah ke STKS Bandung karena disana sudah menjurus itu pun S2-nya klinis. Tapi mungkin juga disana anda mendapat spesialisasi lebih menjurus atau spesifik, tetapi ada negatifnya, negatifnya adalah anda tidak bisa mengkoneksikan dengan ke-Islaman. ${ }^{29}$

Untuk itu, semua stakeholder perlu mengakomodir kebutuhan yang sesungguhnya apa yang dibutuhkan oleh pasar dan mahasiswa. Apakah hanya sebatas ijazah atau ilmunya juga. Jadi IIS perlu punya ideologi yang progresif. Semua dosen ditatar melalui workshop, workshopnya harus keberpihakan. Islam betul, tapi Islam yang berpihak pada orang yang marginal, orang lemah, tafsir Islam juga mengarah ke sana mestinya. Selain evaluasi secara general mengenai keberadaan IIS, evaluasi program pun dalam proses pengajaran pada setiap individu dosen perlu dilakukan. Mengingat hasil evaluasi akan menentukan paradigma serta arah pengembangan Prodi IIS ke depan. Sebagaimana disampaikan oleh narasumber sebagaimana berikut:

Saya melakukan evaluasi dengan melihat review hasil pengayaan materi, kemudian melihat lagi apa yang kurang untuk disampaikan kepada mahasiswa. Secara general, evaluasi penerapan konsep integras-interkoneksi dari pusat kurang bahkan mungkin bisa dikatakan menurun, tidak ada tindak lanjut program evaluasi, setelah pak Amin turun dari jabatan Rektor. Selama ini yang ada hanya semacam kalender akademik yang berjalan, tetapi secara tentatif pengadaan workshop, evaluasi dosen secara menyeluruh memang mengalami kemunduran. Saya tidak menemukan saat ini, semisal dari lembaga penjaminan mutu mengaudit bagaimana kinerja dosen dalam melakukan proses pembelajaran, dari masing-masing jurusan itu dengan kurikulum mengedepankan konsep integrasi-interkoneksi tadi, hal ini belum pernah ada. ${ }^{30}$ 
Dari hasil kutipan di atas, memang sangat disayangkan oleh semua pihak, khususnya bagi dosen pengampu mata kuliah setelah Prof. Dr. H. M. Amin Abdullah, lengser dari jabatan Rektor semua program kurikulum berbasis integrasi dan interkoneksi seakan putus begitu saja. Apalagi bila berbicara IIS, tidak semua dosen melakukan evaluasi tersebut sehingga boleh dikatakan mengalami stagnasi pemikiran dan pembaruan dalam dinamika perkuliahan di kelas. Lain hal, disampaikan juga oleh narasumber sebagaimana hasil kutipan berikut:

Kita tidak bisa merasa bahwa mata kuliah umum itu paling penting, tetapi bagi saya harus adanya tegur sapa, kita tetap mengkaitkan jadi kita nanti aplikasinya bagaimana ilmu yang kita pelajari ini ternyata tidak bisa lepas, tidak bisa putus begitu saja dengan ilmu yang lain, jadi kita nanti saling sinergi, jadi keilmuan ini bisa terbantu dengan ilmu ini, dengan cara begini untuk kita aplikasikan, saling melengkapi, dikaitkan jadi ketika kita bercerita persoalan ilmu agama ya kita pasti akan saling membutuhkan untuk mencoba saling tegur sapa. ${ }^{31}$

Aplikasi integrasi dan interkoneksi dalam satuan pembelajaran di atas, seyogyanya kita dapat menilai bahwa secara umum sudah menerapkan paradigma tersebut. Namun, hanya saja ada sebagian dosen yang belum menerapkannya dengan berbagai alasan. Sehingga perlu ada kesinambungan antara dosen satu dengan lainnya melalui agenda workshop, penulisan antologi, penyeragaman SAP dalam pendekatan penyampaian isi materi, dan lainnya. Alasan lain adalah melihat peta pengembangan Prodi ke depan menjadi sangat mutlak dibutuhkan antara stakeholder satu dengan pihak-pihak terkait.

\section{RESPON MAHASISWA TERHADAP APLIKASI INTEGRASI- INTERKONEKSI}

Tanggan mahasiswa dalam proses pembelajaran memakai paradigma integrasi dan interkoneksi memang beragam. Ini dilandasi oleh pemahaman mahasiswa mengenai paradgima itu berbeda-beda antara satu pihak dengan pihak lain. Ada yang berbicara mengenai pemikiran dosen di UIN itu liberal, terlalu skeptis dan lainnya. Demikian ini, akan membuat dinamika proses pembelajaran menjadi semakin dialektis. Pernyataan terkait ini sebagaimana hasil kutipan hasil wawancara berikut:

Sejauh ini memang saya lihat background dosen kita dari luar yah, saya 
fahami justru malah ini menurut pemahaman saya dosennya cukup liberal, mungkin lebih tepatnya cukup nasionalis biar lebih enak didengar. Untuk ke ideologi Islamnya ada beberapa dosen yang mungkin kan ada mata kuliah kan ada Pekerjaan Sosial Berbasis Agama, cuman dipahami secara keseluruhan saya lihat ideologi di IIS yang memang basic bckground agamanya itu jauh dan ini pemahaman saya ya, maksudnya apa karena kita lebih kepada sosialnya secara umum jadi karena agama yang dinilai di IIS ini bukan agama yang satu-satu, seperti ini Islam loh, akan tetapi tidak seperti itu. jadi pekerja sosial yang berbasis agama pemahaman ideologi IIS ini adalah semua agama, semua kepercayaan. Seperti kita kan mempunyai aturan, normanorma tersendiri yah kan. ${ }^{32}$

Persoalan lain dari persepsi mahasiswa mengenai proses pembelajaran pada Prodi IIS mereka melihat bahwa IPI dan Peksos merupakan kedua rumpun yang berbeda sehingga bagi dosen dalam menyampaikan materi perkuliahan perlu inovasi. Tapi memang sejauh ini mahasiswa beranggapan paradigma integrasi dan interkoneksi dalam pembelajaran di terapkan oleh para dosen. Pernyataan ini diperjelas hasil kutipan wawancara sebagaimana berikut:

Pertama, memang secara pribadi banyak muatan keilmuannya berbeda.

Antara pekerjaan sosial dengan ilmu perpustakaan dan imformasi khususnya untuk praktik di lapangan. Kalau memang sama berbicara pengembangan keilmuan sesuai dengan kajian pustaka. Karena memang secara rumpunnya sangat susah. Kedua, yang namanya inovasi itu butuh banyak hal, ada dana, persiapan, sarana prasarana, termasuk kesiapan dosen, saya hanya memandang secara luas memang secara idealnya dipisahkan dengan prodi sendiri-sendiri. Tapi karena seperti itu, ya kita ngamini saja. ${ }^{33}$

Belajar adalah kewajiban bagi setiap manusia, mulai dari lahir hingga sampai akhir hayat. Begitulah yang Islam doktrin bagi pemeluknya. Dalam hal ini jenjang Strata-2, merupakan jenjang selanjutnya dari pendidikan formal. Dari hal ini bisa kita katakan bahwa mencari ilmu tidak ada batasan, baik anak-anak, muda ataupun tua. Selain itu alasan yang cukup rasional lagi mengenai kegiatan yang bisa dikatakan membutuhkan kegiatan lain agar terus berpikir agar tidak stagnan, dengan kegiatan-kegiatan yang cukup padat seperti mengisi untuk diskusi-diskusi dan lain-lain maka memutuskan untuk mengambil program pascasarjana di UIN Sunan Kalijaga merupakan langkah sebagai pengembangan keilmuan. 
Selain itu, jurusan IIS: IPI dan Peksos mencoba merespon kebutuhan pengembangan pola pengejaran integrasi dan interkoneksi studi dalam keilmuan pengembangan masyarakat Islam, IImu Perpustakan ataupun Kesejahteraan Sosial. Kemudian, IIS juga sebagai jurusan yang memiliki studi keislaman dan ilmu sosial bagi kemanusiaan sehingga Pekerjaan Sosial yang awalnya hanya dikenal di luar negeri, dengan adanya Jurusan IIS bisa menjadikan media pengenalan dan penegasan profesi Pekerjaan sosial di Indonesia karena dalam lingkup dunia internasional jenjang pendidikan pekerjaan sosial sudah ada dalam setiap tingkatan; S1, S2, S3.

Dengan begitu, dalam implementasi pengembangan lanjutan di Indonesia dua konsentrasi dalam satu payung seyogyanya dapat saling keterpaduan antara satu sama lain. Mengingat landasan awal interdisipliner itu sendiri merupakan pengejawantahan dari satu paradigma integrasiinterkoneksi yang selama ini diterapkan di UIN Sunan Kalijaga, baik pada ranah administratif maupun kerangka acuan penyusunan kurikulum pembelajaran di kampus. Untuk itu, berikut hasil pemahaman mahasiswa dan tanggapannya mengenai paradigma integrasi-interkoneksi, diperjelas sebagaimana berikut:

Integrasi-interkoneksi itu pandangan yang multidisipliner mengenai satu fenomena sosial, apa yang sudah berlangsung dalam proses pembelajaran di IIS seyogyanya sudah mencerminkan hal tadi. Kalau kita menggunakan perspektif multidisipliner dalam memahami dan mencari solusi terkait permasalahan sosial, terutama mengenai informasi kepustakaan. ${ }^{34}$

Dari penjelasan mengenai pandangan integrasi dan interkoneksi di atas, sebetulnya mahasiswa secara umum sudah mengetahui proses pembelajaran dari aplikasi paradigma itu tadi. Tanggapan mahasiswa IPI akan sangat berbeda dengan padangan mahasiswa Peksos tentunya. Hal ini tercermin bagaimana mereka memahami konteks ilmu yang diserap oleh para dosen ketika proses perkuliahan berlangsung. Sebagai contoh, aplikasi integrasi dan interkoneksi yang dimaksudkan dalam hal ini mengenai fenomena sosial. Problem sosial merupakan salah satu isu yang dapat dikembangkan melalui berbagai landasan filosofis multidisipliner. Semisal, memahami anak dalam pandangan multidisipliner bahwa kajian ini sama-sama untuk membebebaskan, konteks ini pun semangat intervensi terhadap anak yang memiliki masalah seyogyanya senafas dengan Islam. Persoalan ini diperjelas oleh salah satu mahasiswa Peksos sebagaimana berikut: 
Sebagian iya, sebagian tidak. Contoh bagi pandangan saya terkait aplikasi integrasi-interkoneksi yang diterapkan dosen dala memahami fenomena sosial. Alih-alih kita memandang kekerasan dalam anak, menurut saya semisal larangan di dalam Alquran, bisa memandang bahwa pengetahuan yang dikembangkan mengenai salah satunya sebagai contoh sociologi of childhood itu mengacu kepada pembebasan anak dan kungkungan struktur masyarakat. Hal ini sejalan dengan Islam sebagai agama yang membebaskan. Jadi, menurut saya pandangan integrasi-interkoneksi itu tidak langsung diterapkan dalam arti ini menerapkan pandangan integrasi-interkoneksi tetapi jauh dari itu. Pandangan integrasi-interkoneksi itu ketika kita berusaha memahami suatu masalah dengan banyak jalan, salah satunya jalan yang dikembangkan dalam ilmu-ilmu yang berkaitan dengan agama Islam. ${ }^{35}$ Penjelasan di atas, meniscayakan sebuah perumpamaan yang mapan antara ilmu umum dengan agama dapat melebur menjadi satu ketika menjelaskan satu fenomena mendasar, semisal persoalan anak. Untuk itu, tiada lain bagi mahasiswa paradigma integrasi dan interkoneksi yang digunakan sebagai landasan mendasar bagi semua aktivitas pembelajaran di kampus, khususnya bagi IIS, ini merupakan sudah menjadi kesadaran bagi mahasiswa betapa terinternalisasikannya paham integrasi dan interkoneksi sehingga tidak lagi ada pelabelan ilmu-ilmu yang sudah disebutkan jauh sebelumnya.

Maka dari itu, pemahaman mahasiswa mengenai aplikasi integrasi dan interkoneksi dalam proses pembelajaran tidak hanya berhenti sampai pada aplikasi SAP, diskusi di kelas maupun lainnya, harus jauh dari itu dipahami sebagai satu paradigma yang utuh dengan spesifikasi kajian yang komprehensif. Sehingga ketika dihadapkan persoalan sosial mahasiswa bisa memetakan apa yang dibutuhkan masyarakat. Tetapi tidak kemudian terkooptasi dalam satu pandangan ilmu saja.

\section{PENUTUP}

Perubahan sosial di era kekinian telah melahirkan ragam perspektif baru dalam wacana keilmuan. Istilah post modernisme dikalangan intelektual semakin menunjukan bahwa peradaban pengetahuan begitu cepat mengalami moderasi-walaupun beberapa kalangan tidak sepakat dengan pelabelan post-modern ini. Posisi demikian terus memacu para intelektual untuk terus berbenah diri dengan melahirkan karya dalam mengisi pembaharuan ilmu. Tak terkecuali para intelektual Islam.

Berbicara intelektual Islam tentunya kita telah memiliki banyak aktoraktor pembaharu di dalamnya. Sebut saja Nasr Abu Sayyed, Asgar Ali 
Engineer, Yusuf al-Qordhawi, Mohammad Arkoun, Ibn Khaldun, dan masih banyak tokoh lain di dunia. Di Indonesia sendiri kita kenal para cendikiawan Muslim, semisal Harun Nasution, Mukti Ali, Nurcholish Madjid, mungkin sosok bersahaja di era saat ini ada Amin Abdullah.

Mereka merupakan sosok para intelektual Islam (cendikiawan Muslim Indonesia) yang mampu membawa peradaban baru bagi perkembangan keilmuan Islam ditengah ke-'jumudan' masyarakat. Munculnya ideologisasi, truth claim kelompok-kelompok kecil, bahkan ragam pemikiran yang intolerir ditengah budaya kita, munculnya term pemahaman fundamentalisme, liberalisme bahkan terorisme. Satu sisi bagi seorang ilmuwan Muslim munculnya ragam pemikiran itu merupakan fitrah. Tapi disisi lain munculnya term tersebut membuat satu keresahan sendiri bagi masyarakat Indonesia yang sudah mapan dengan konsep saling menghargai satu sama lain.

Pada ranah perguruan tinggi, munculnya pemikiran di atas merupakan sebuah keharusan bagi para civitas akademika untuk senantiasa melakukan pembaharuan dan penelitian terkait. Guna mewujudkan sebuah perspektif baru bagi berkembangan ilmu-ilmu dan pengetahuan Islam untuk kehidupan generasi mendatang. Namun, seiring berkembangnya waktu pengembangan ke-IImuwan dalam Islam mengalami perdebatan alot. Di mana para sarjana Muslim, khususnya, di era dahulu pengetahuan itu terkotak-kotakan bagaikan bungkus nasi yang sudah ada lauk pauk di dalamnya. Orang akan makan daging dengan rasa berbeda dari bungkus yang lain seolah terkesan tidak bisa dicoba karena sudah memiliki porsi masing-masing. Walhasil, bila kita ingin memakan bungkus nasi dengan rasa masakan Padang semisal, tak lantas kemudian mudah bisa mengambil bungkus nasi tadi, karena barangkali bungkus nasi sudah dimasukan rasa masakan Sunda. Analogi ini mengibaratkan kita dihadapkan pada kotakkotak ilmu.

Dalam pada itu, artikulasi lebih jauh analogi di atas mengibaratkan semakin pesatnya pemikiran sarjana Muslim mengalami 'kejumudan'. Melihat fakta demikian saatnya Perguruan Tinggi Islam harus peran serta meresponnya dengan cepat dan tepat, termasuk pada kesempatan ini UIN Sunan Kalijaga menjadi garda terdepan untuk mengurai benang kusut tadi. Artinya, institusi UIN Sunan Kalijaga harus bisa melahirkan dan mencetak sarjana Muslim yang dibekali dengan ragam perspektif luas dan komprehensif. 
Adalah sosok Amin Abdullah yang telah mampu mengembangkan perspektif dari telikungan 'kotak-kotak' ilmu tadi dengan paradigma integrasi-interkoneksi dalam ranah aplikasi pembelajaran bagi civitas akademika. Termasuk di dalamnya Prodi Interdisciplinary Islamic Studies (IIS) Program Pascasarjana UIN Sunan Kalijaga. Maka dari itu, paradigma pada proses pembelajaran di IIS seyogyanya telah meletakan paradigma integrasi-interkoneksi sebagai dasar pengembangan terma perkuliahan. Termasuk dari hasil penelitian ini dilihat dari dua terma yakni aplikasi pada ranah lintas disiplin ilmu dan implementasi nilai-nilai ke-Islaman dalam menyampaikan perkuliahan di kelas oleh para dosen pengajar. Sedangkan, untuk implementasi teknis dosen pengampu mata kuliah paradigma integrasi-interkoneksi itu pada tiga ranah berbeda, yaitu aplikasi teknis pada SAP, diskusi di kelas, dan evaluasi pembelajaran.

Tanggapan lain dari mahasiswa bahwa jurusan IIS: IPI dan Peksos mencoba merespon kebutuhan pengembangan pola pengejaran integrasi dan interkoneksi studi dalam keilmuan pengembangan masyarakat Islam, Ilmu Perpustakan ataupun Kesejahteraan Sosial. Kemudian, IIS juga sebagai jurusan yang memiliki studi keislaman dan ilmu sosial bagi kemanusiaan sehingga Pekerjaan Sosial yang awalnya hanya dikenal di luar negeri, dengan adanya Jurusan IIS bisa menjadikan media pengenalan dan penegasan profesi Pekerjaan sosial di Indonesia karena dalam lingkup dunia internasional jenjang pendidikan Pekerjaan Sosial sudah ada dalam setiap tingkatan; S1, S2, S3.

Peletakan nilai-nilai ke-Islaman bagi UIN Sunan Kalijaga adalah satu hal yang esensial dan paling mendasar. Tapi dengan adanya moderasi perkembangan zaman tidak kemudian menutup kemungkinan IImu Agama membuka diri untuk saling tegur sapa di antara satu sama lain. Inilah konsep dasar dari berdirinya Prodi Interdisciplinary Islamic Studies (IIS) Program Pascasarjana UIN Sunan Kalijaga, sehingga melahirkan dua konsentrasi yang secara rumpun keilmuan berbeda. Satu dari rumpun ilmu Sosiologi dengan melahirkan konsentrasi Pekerjaan Sosial dan satu lagi rumpun Ilmu Humaniora dengan melahirkan konsentrasi IImu Perpustakaan dan Informasi.

Memang pada dasarnya kedua konsentrasi yang ada pada prodi IIS ini alasan pragmatis. Akan tetapi, seiring dengan berkembangnya waktu dua term keilmuan berbeda ini dapat dipadukan menjadi satu desain kesatuan peleburan. Tak ayal, aplikasi paradigma integrasi-interkoneksi pada sisi 
administratif dapat dijelaskan dengan baik. Namun, pada corak paradigma keilmuan tidak kemudian dengan mudah menjelaskan secara runtut dan sistematis dari dua perbedaan tersebut.

Maka dari itu, bagi pemegang kebijakan pada Program Pascasarjana UIN Sunan Kalijaga direkomendasikan agar melakukan workshop keilmuan dari kedua konsentrasi yang ada pada Prodi IIS. Ini dilakukan agar dapat dijelaskan secara sinergis antara konsentrasi satu dengan yang lainya. Sehingga output dari dealektika tersebut paling tidak dapat dijadikan sebagai rekomendasi awal untuk pembenahan secara keilmuan seiring dengan berkembangnya wacana pemisahan dua konsentrasi itu tadi.

Selanjutnya, melalui forum diskusi dan ilmiah sebagaimana yang telah direkomendasikan, bahwasanya aplikasi integrasi-interkoneksi pada Prodi IIS tadi butuh acuan yang jelas mengenai konsep dasar dari paradigma integrasi-interkoneksi. Karena tidak semua mata kuliah yang ada pada dua konsentrasi dapat menggunakan paradigma integrasi-interkoneksi. Sehingga output lebih lanjut dapat dijelaskan dengan sistematis bagian mana saja ilmu-ilmu yang tersaji ke dalam mata kuliah yang dapat diintegrasikan dan diinterkoneksikan.

\section{CATATAN AKHIR}

1 M. Amin Abdullah, Islamic Studies di Perguruan Tinggi Pendekatan IntegratifInterkonektif, (Yogyakarta: Pustaka Pelajar, 2006).

2 Fahrudin Faiz, "Mengawal Perjalanan Sebuah Paradigma" dalam Fahrudin Faiz (ed.), Islamic Studies dalam Paradigma Integrasi-Interkoneksi, (Yogyakarta: SUKA Press, 2007), h. 1-7.

3 Siswanto, "Perspektif Amin Abdullah Tentang Integrasi Interkoneksi dalam Kajian Islam”, Teosofi: Jurnal Tasawuf dan Pemikiran Islam, Vol. 3 No. 2 (2013), h. 1 .

4 Lihat, Harun Nasution, "Klasifikasi Ilmu dan Tradisi Penelitian Islam: Sebuah Perspektif," dalam M. Deden Ridwan (Ed.), Tradisi Baru Penelitian Agama Islam: Tinjauan Antardisiplin Ilmu, (Bandung: Yayasan Nuansa Cendekia, 2001), h. 27-28.

5 Sekolah Pascasrjana UIN Sunan Kalijaga membuka 12 konsentrasi, yakni (1) Konsentrasi Islam Nusantara (Isnus); (2) Konsentrasi Islam, Pembangunan dan Kebijakan Publik (IPKP); (3) Konsentrasi Kajian Komunikasi dan Masyarakat Islam (KKMI); (4) Konsentrasi Hermeneutika Alquran (HQ); (5) Konsentrasi Psikologi Pendidikan Islam (PsiPI); (6) Konsentrasi Islam dan Kajian Gender (IKG); (7) Konsentrasi Kajian Timur Tengah (KTT); (8) Konsentrasi Studi Disabilitas dan Pendidikan Inklusif (SDPI); (9) Konsentrasi Kajian Maqasid dan Analisis Strategik (KMAS); (10) Konsentrasi Pekerjaan 
Sosial (Peksos); (11) Konsentrasi Ilmu Perpustakaan dan Informasi (IPI); (12) Konsentrasi Bimbingan dan Konseling Islam (BKI). Lihat, http://pps.uinsuka.ac.id/id/?option=com_content\&view $=$ article\& $i d=39 \&$ Itemid $=151$.

6 Lihat selengkapnya al-Farabi, Ihsha al-'Ulum, Paris: Dar Biblion.

7 Al-Ghazali, Ihya 'Ulum al-Din, juz 1, h. 17.

8 Ibn Khaldun, Muqaddimah, terj. Franz Rozenth.

9 Osman Bakar, Classification of Knowlwdge in Islam, (Kuala Lumpur: Institute for Policy Reaserch, 1992).

10 Mulyadi Kartanegara, Integrasi Ilmu, (Bandung: Arasy Mizan, 2005).

11 Amin Abdullah, Islamic Studies di Perguruan Tinggi Pendekatan IntegratifInterkonektif, (Yogyakarta: Pustaka Pelajar, 2012).

12 M. Amin Abdullah dkk., Kerangka Dasar Keilmuan dan Pengembangan Kurikulum Universitas Islam Negeri (UIN) Sunan Kalijaga, (Yogyakarta: Pokja Akademik UIN Sunan Kalijaga, 2006).

13 Mukti Ali, Memahami Beberapa Aspek Ajaran Islam, (Bandung: Mizan, 1991), h. 19.

14 Nurcholis Madjid, Islam Doktrin dan Peradaban Sebuah Telaah Kritis tentang Masalah Keimanan, Kemanusiaan, dan Kemodernan, (Jakarta: Yayasan Wakaf Paramadina, 2000).

15 Lihat, M. Amin Abdullah, Islamic Studies di Perguruan Tinggi Pendekatan IntegratifInterkonektif, (Yogyakarta: Pustaka Pelajar, 2012).

16 M. Amin Abdullah, dkk, Kerangka Dasar Keilmuan dan Pengembangan Kurikulum Universitas Islam Negeri Sunan Kalijaga, (Yogyakarta, Pokja UIN Suka, 2006), h. 104.

17 M. Amin Abdullah, Islamic Studies di Perguruan Tinggi Pendekatan IntegratifInterkonektif, (Yogyakarta: Pustaka Pelajar, 2006), h. 107.

18 Wawancara pribadi dengan Drs. Latiful Khuluq, Ph.D di Kantor Dosen Jurusan Ilmu Kesejahteraan Sosial Fakultas Dakwah dan Komunikasi UIN Sunan Kalijaga, pada tanggal 27 Oktober 2014, pukul 12.50 WIB.

19 Wawancara dengan Muhammad Izzul Haq, M.Sc di Ruang Sekretariat Jurusan Ilmu Kesejahteraan Sosial Fakultas Dakwah dan Komunikasi UIN Sunan Kalijaga, pada tanggal 11 November 2014, pukul 11.00 WIB.

20 Wawancara pribadi dengan Drs. Latiful Khuluq, Ph.D di Kantor Dosen Jurusan Ilmu Kesejahteraan Sosial Fakultas Dakwah dan Komunikasi UIN Sunan Kalijaga, pada tanggal 27 Oktober 2014, pukul 12.50 WIB.

21 Wawancara dengan Dr. Sriharini di Kantor Pembantu Dekan 3 Fakultas Dakwah dan Komunikasi UIN Sunan Kalijaga, pada tanggal 11 November 2014, pukul 11.00 WIB.

22 Wawancara dengan Muhammad Izzul Haq, M.Sc di Ruang Sekretariat Jurusan Ilmu Kesejahteraan Sosial Fakultas Dakwah dan Komunikasi UIN Sunan Kalijaga, pada tanggal 11 November 2014, pukul 11.00 WIB.

23 Course Outlet Mata Kuliah Pendekatan dalam Studi Islam, Oleh: Dr. Phil. Sahiron Syamsudin, MA dalam acuan pembelajaran tahun 2013/2014, Semester Gasal. 
24 Course Outline Mata Kuliah Perspektif Kesejahteraan Sosial dalam Qur'an, Dosen Pengampu Dr. Waryono Abdul Ghofur, M.Ag, tahun pembelajaran 2013/2014, semester Genap.

25 Wawancara dengan Dra. Labibah, M.Lis di Ruang Dosen Ilmu Perpustakaan dan Informasi Fakultas Adad dan Ilmu Budaya UIN Sunan Kalijaga, pada tanggal 13 November 2014, pukul 10.00 WIB.

26 Wawancara dengan Muhammad Izzul Haq, M.Sc di Ruang Sekretariat Jurusan Ilmu Kesejahteraan Sosial Fakultas Dakwah dan Komunikasi UIN Sunan Kalijaga, pada tanggal 11 November 2014, pukul 11.00 WIB.

27 Wawancara dengan Hj. Sri Rohkyanti Zulaikha, SIP, M.Si, melalui email pada tanggal 8 Desember 2014.

28 Wawancara pribadi dengan Drs. Latiful Khuluq, Ph.D di Kantor Dosen Jurusan Ilmu Kesejahteraan Sosial Fakultas Dakwah dan Komunikasi UIN Sunan Kalijaga, pada tanggal 27 Oktober 2014, pukul 12.50 WIB.

29 Wawancara pribadi dengan Drs. Latiful Khuluq, Ph.D di Kantor Dosen Jurusan Ilmu Kesejahteraan Sosial Fakultas Dakwah dan Komunikasi UIN Sunan Kalijaga, pada tanggal 27 Oktober 2014, pukul 12.50 WIB.

30 Wawancara dengan Muhammad Izzul Haq, M.Sc di Ruang Sekretariat Jurusan Ilmu Kesejahteraan Sosial Fakultas Dakwah dan Komunikasi UIN Sunan Kalijaga, pada tanggal 11 November 2014, pukul 11.00 WIB.

31 Wawancara dengan Dr. Sriharini di Kantor Pembantu Dekan 3 Fakultas Dakwah dan Komunikasi UIN Sunan Kalijaga, pada tanggal 11 November 2014, pukul 11.00 WIB.

32 Wawancara dengan Fitri Yulianti, di kelas pada tanggal 29 Oktober 2014, pada pukul 11.00 WIB.

33 Wawancara dengan Nung, di Caffe pada tanggal 15 Oktober 2014, pada pukul 19.30 WIB.

34 Wawancara dengan Triyono mahasiswa IPI di Kantor Perpustakaan Kota Yogyakarta, pada tanggal 28 Oktober 2014, pukul 12.30 WIB.

35 Wawancara pribadi dengan Miftahur Ridho di Kontrakan pada tanggal 27 Oktober 2014, pukul 20.50 WIB.

\section{DAFTAR PUSTAKA}

Abdullah, M. Amin. 2012. Islamic Studies di Perguruan Tinggi Pendekatan IntegratifInterkonektif. Yogyakarta: Pustaka Pelajar.

Abdullah, M. Amin, dkk. 2006. Kerangka Dasar Keilmuan dan Pengembangan Kurikulum Universitas Islam Negeri (UIN) Sunan Kalijaga. Yogyakarta: Pokja Akademik UIN Sunan Kalijaga.

Abdullah, M. Amin. 2006. Islamic Studies di Perguruan Tinggi Pendekatan IntegratifInterkonektif. Yogyakarta: Pustaka Pelajar.

Abdullah, M. Amin, dkk. 2003. Rekonstruksi Metodologi Ilmu-Ilmu Keislaman.

Yogyakarta: Suka-Press.

al-Farabi. Ihsha al'Ulum. Paris: Dar Biblion.

Al-Ghazali. Ihya 'Ulum al-Din, juz 1. 
Ali, Mukti. 1987. Beberapa Persoalan Agama Dewasa Ini. Jakarta: Rajawali Press.

Ali, Mukti. 1991. Memahami Beberapa Aspek Ajaran Islam. Bandung: Mizan.

Arikunto, Suharsimi. 2002. Prosedur Penelitian Suatu Pendekatan Praktek. Cetakan ke-12. Jakarta: PT. Rineka Cipta.

Ausburg, Tanya. 2006. Becoming Interdisciplinary: An Introduction to Interdisciplinary Studies, $2^{\text {nd }}$ edition. New York: Hunt Publishing.

Bakar, Osman. 1992. Classification of Knowlwdge in Islam. Kuala Lumpur: Institute for Policy Reaserch.

Benson, C. Thomas. 1982. "Five Argument Againts Interdisciplinary Studies." Issues in Integrative Studies, No. 1.

Biber and Leavy. 2006. The Practice of Qualititative Research. Thousand Oak. California: Sage Publication.

Creswell, J.W. 2007. Qualitative Inquiry and Reseacrh Design: Choosing Among Five Traditions. Thousand Oaks: CA: Sage.

Faiz, Fahrudin. 2007. "Mengawal Perjalanan Sebuah Paradigma" dalam Fahrudin Faiz (ed.), Islamic Studies dalam Paradigma Integrasi-Interkoneksi. Yogyakarta: SUKA Press.

Ibn Khaldun, Muqaddimah, terj. Franz Rozenth.

Kartanegara, Mulyadi. 2005. Integrasi Ilmu. Bandung: Arasy Mizan.

Klein, J. T., \& Newell, W.H. 1997. "Advancing Interdisciplinary Studies” in Jerry Gaff \& James Ratcliff (eds.). Handbook of the Undergraduate Curriculum: A Comprehensive Guide tu Purposes, Structure, Practices and Change. (San Francisco: Josse -Bass.

Klein, Julie Thompson. 1990. Interdisciplinarity; History, Theory and Practice. Detroit: Wayne State University.

Madjid, Nurcholis. 2000. Islam Doktrin dan Peradaban Sebuah Telaah Kritis tentang Masalah Keimanan, Kemanusiaan, dan Kemodernan. Jakarta: Yayasan Wakaf Paramadina.

Mansilla, Veronica Boix. 2005. "Assessing Student Work at Disciplinary Crossroad". Change: The Magazine of Higher Learning.

Merriam, S.B. 2002. Qualitative Reseacrh in Practice: Example for Duscussion and Analisys. San Fransisco: Jossey Bass.

Miles and Huberman. 1994. Qualitative Data Analisys. Thousand Oaks: Sage Publication.

Moran, Joe. 2010. Interdisciplinary (The New Critical Idiom). New York: Routledge.

Moran, Lexy J. X. 2010. Metodologi Penelitian Kualitatif. Bandung: PT. Remaja Rosdakarya.

Nasution, Harun. 2001. "Klasifikasi Ilmu dan Tradisi Penelitian Islam: Sebuah Perspektif,” dalam M. Deden Ridwan (Ed.). Tradisi Baru Penelitian Agama Islam: Tinjauan Antardisiplin Ilmu. Bandung: Yayasan Nuansa Cendekia.

Repko, f. Allen. 2010. Interdisciplinary Research: Process and Theory. Routledge.

Siswanto. 2013. "Perspektif Amin Abdullah Tentang Integrasi Interkoneksi dalam Kajian Islam”, Teosofi: Jurnal Tasawuf dan Pemikiran Islam, Volume 3 Nomor 2 Desember. 
Stake, R.E. 1995. The Art of Case Study. Thousand Oaks: Sage Publication.

Stember, M. 1991. "Advancing the Social Sciences through the Interdisciplinary Enterprise". The Social Science Journal, 28(1).

Sugiyono. 2013. Memahami Penelitian Kualitatif. Bandung: Alfabeta.

Suprayoga, Iman dan Tobroni. 2003. Metodologi Penelitian Sosial-Agama. Bandung: PT Remaja Rosdakarya. 